\title{
LEHET-E HATÁSA A VÁLLALATI ÖNKÉNTESSÉGNEK A VÁLLALATI VERSENYKÉPESSÉGRE? - GONDOLATOK A TÉMÁRÓL ELMÉLETI MEGKÖZELITTÉSBEN ${ }^{1}$
}

DOI: https://doi.org/10.53585/OnkSzem.2022.1.45-62

\section{Absztrakt}

A vállalati önkéntesség a vállalati társadalmi felelősségvállalás (CSR) egyik tevékenységtípusának tekinthető. Az elmúlt években, évtizedekben számos kutatás vizsgálta főként nemzetközi viszonylatban a CSR társadalmi, gazdasági hatásait, köztük azt is, hogy lehet-e a CSR aktivitásnak akár pénzügyi hatása a vállalatra, ezáltal akár a versenyképességre is. Az utóbbi években az érdeklődés középpontjába került szintén főként külföldön, hogy a CSR egyik elemének a vállalati önkéntességnek milyen hatása lehet a vállalati múködésre. A tanulmány arra keresi a választ elméleti megközelítésben, hogy a vállalati önkéntességnek is lehet-e hatása a vállalati versenyképességre? A tanulmány a CSR versenyképességre gyakorolt hatásaiból indul ki és ez alapján közelíti meg a vállalati önkéntesség és a versenyképesség témát. A tanulmány hazai és nemzetközi szakirodalmak és néhány hazai kutatás alapján vizsgálja a kérdést, illetve mindez kiegészül a szerző saját korábbi tapasztalatai alapján megfogalmazott gondolatokkal. A tanulmány egyik fő megállapítása, hogy az eddigi gyakorlatok alapján a vállalati önkéntesség jellemzően a nagyvállalatokra jellemző, bár még körükben is alacsony a valóban aktívak száma és kevésbé jellemző az önkéntesség hatásainak vizsgálata is. Ez utóbbi pedig azt jelenti, hogy bár az elmélet alapján megragadható a vállalati önkéntesség és vállalati versenyképesség kapcsolatának témája, a gyakorlatban ehhez szükség lenne a tevékenység mélyebb értékelésére, a vállalati múködésben való jobb pozicionálására. A téma rendkívül összetett, hiszen a vállalatok nagyon különbözőek, így általánosságok megfogalmazására a tanulmány nem törekszik, arra viszont igen, hogy rámutasson jelenségekre, összefüggésekre a témával kapcsolatban, amely segítség lehet mind a téma kutatóinak, mind vállalati szakembereknek.

Kulcsszavak: vállalati társadalmi felelősségvállalás (CSR), vállalati önkéntesség, vállalati versenyképesség, hatás,

\footnotetext{
${ }^{1}$ A tanulmány a Bolyai János Kutatási Ösztöndíj támogatásával készült.

${ }_{2}^{2}$ Reisinger Adrienn (PhD) közgazdász, habilitált egyetemi docens, tudományszervezési dékánhelyettes, Széchényi István Egyetem
} 


\section{Is there any relation between corporate volunteering and corporate} competitiveness? - A theoretical approach

\section{Adrienn Reisinger}

\section{Abstract}

Corporate volunteering can be considered as an element of corporate social responsibility (CSR). In recent decades, numerous studies have examined the social and economic effects of CSR, mainly in an international context, including whether CSR activities financially impact the company's operation and thus their competitiveness. The impact of corporate volunteering, one of the elements of CSR on corporate operations has become the focus of research, mainly abroad. This study seeks to answer the question, from a theoretical perspective, whether corporate volunteering can also have an impact on corporate competitiveness. The paper draws on domestic and international literature and some research conducted domestically, and is complemented by the author's own reflections on their experience. One of the main findings of the study is that, based on existing practices, corporate volunteering is typically found in large companies, although even among them, the number of truly active volunteers is low, and the impact of volunteering is not researched thoroughly. The latter means that, although the relationship between corporate volunteering and corporate competitiveness can be addressed on the basis of theory, in practice, it would require a deeper assessment of the activity and a better positioning of the activity in corporate operations. The topic is extremely complex, as companies are diverse, so the study does not aim to formulate generalities; however, it points out phenomena and relation on the topic, which may be helpful for both researchers and corporate professionals.

Keywords: corporate social responsibility (CSR), corporate volunteering, corporate competitiveness, impact

\section{BEVEZETÉS}

A vállalati társadalmi felelősségvállalás (CSR) széles körben vizsgált, elemzett téma, ahogyan főként külföldön az is, hogy a CSR tevékenységek jelenthetnek-e versenyelőnyt a vállalatok számára? Hazánkban azonban még csak kevesen foglalkoznak tudományos oldalról ezekkel a kérdésekkel, a CSR egy konkrét tevékenységével, a vállalati önkéntességgel pedig még kevesebben. A hazai publikációkban egyelőre még feltáratlan terület a vállalati önkéntesség elméletének és gyakorlatának részletes bemutatása, a tevékenység versenyképességhez történő kapcsolása pedig csak elvétve jelenik meg. Noha maga a CSR sokat kutatott téma, ezen belül a vállalati önkéntesség versenyelőnyre gyakorolt hatása még egy kutatási résnek számít. A tanulmány célja, hogy hazai és nemzetközi szakirodalmi feldolgozás alapján és saját gondolatokkal kiegészítve bemutassa a vállalati önkéntesség és a vállalati versenyképesség közötti lehetséges kapcsolódásokat. A kérdés, hogy lehet-e a vállalati önkétességnek hatása a versenykésességre? Mivel a hazai irodalomban ez a téma inkább csak közvetetten jelenik meg, 
így célom, hogy egy rövid elméleti áttekintést adjak róla, ezzel is segítve a témát kutató és a gyakorló szakemberek munkáját. További célom az is, hogy felhívjam a figyelmet a társadalmi felelősségvállalásnak, ezen belül a vállalati önkéntességnek mennyire széles körűen értelmezhető és milyen sok oldalról megközelíthető hatása, értéke lehet mind a vállalatra, mind a környezetére nézve.

A tanulmány első felében röviden meghatározom az érintett fogalmak értelmezését (vállalati társadalmi felelősségvállalás, vállalati önkéntesség, vállalati versenyképesség), majd körbejárom a CSR és versenyképesség témáját, ami felvezetésül szolgál az elemzés központi kérdésköréhez, a vállalati önkéntesség és a versenyképesség kapcsolatának vizsgálatához. Az elméleti megközelítés eredményeit összegezve javaslatokat fogalmazok meg a vállalati önkéntesség és versenyképesség összekapcsolására vonatkozólag.

\section{FOGALMI MAGYARÁZATOK}

$A z$ alfejezet célja, hogy röviden ismertesse a tanulmányban érintett jelenségek, úgymint vállalati társadalmi felelősségvállalás (corporate social responsibility - CSR), a vállalati önkéntesség és a vállalati versenyképesség értelmezését. Ezeket a fogalmakat már sokan sokféleképpen megfogalmazták itthon és külföldön egyaránt, így nem célom ezek részletes áttekintése, inkább a tanulmányban használt értelmezésük bemutatására teszem a hangsúlyt.

\section{Vállalati társadalmi felelősségvállalás (CSR)}

A vállalati társadalmi felelősségvállalás témakörének könyvtárnyi irodalma van ma már. Kis túlzással talán azt is mondhatnánk, hogy annyi féle definíciója létezik, ahány szerző írt már róla. Az azonban biztos, hogy annak ellenére, hogy a CSR koncepciója már közel hét évtizede ${ }^{3}$ létezik, még ma sincs egy általánosítható definíciója (Sarkar - Searcy 2016). Ez adódhat abból is, hogy a CSR megközelítésében a fókusz folyamatosan változott az idők során (Carroll Shabana 2010), mivel változott a társadalmi és gazdasági környezet, így változott a felelősségvállalás és a társadalmi felelősségvállalás értelmezése is. Ettől függetlenül természetesen megvannak azok a keretek, melyekkel jól körülírható a CSR jelensége.

\footnotetext{
${ }^{3}$ A vállalati társadalmi felelősség eszméje már megjelent a 20. század első felében is (Radácsi 2021), azonban magát a fogalom megszületését Bowen 1953-as múvéhez kötik.
} 
A CSR egy korai megfogalmazását olvashatjuk Keith Davis múvében (1960:70. cit. András Rajcsányi-Molnár 2014:7), mely szerint a CSR „,...üzletemberek olyan döntései és cselekvései, amelyek legalább részben a cég közvetlen gazdasági, illetve szakmai érdekein kívül történnek." Talán a legtöbbet hivatkozott koncepció Carroll piramis modellje (Caroll 1979; 1991), amely a CSR négy szintjét különböztette meg: a gazdasági, a jogi, az etikai és a filantróp szintet. Az első három a vállalat belső múködésére vonatkozik inkább, míg a negyedik szint a vállalat társadalmi jelenlétére, a társadalmi igényekre való reagálást jelenti változatos formában. Kotler és Lee (2007:11) szerint „a vállalati társadalmi felelősségvállalás azt az elkötelezettséget jelenti, amely során a vállalat a közösség jólétének érdekében folytat önkéntesen, szabadon választott gyakorlatot, amit erőforrásaival támogat."

A vállalati társadalmi felelősségvállalás értelmezése, kereteinek megalkotása fontos az Európai Unió szintjén is, az Európai Bizottság legújabb értelmezése szerint a CSR „a vállalkozásoknak a társadalomra gyakorolt hatásuk iránti felelőssége" (European Commission 2011:7). Ebben a definícióban a fókusz azon van, hogy a vállalatok milyen módon tudnak hatást gyakorolni a társadalmi folyamatokra, erre vonatkozóan pedig milyen felelősségük van. Úgy gondolom, hogy ez a megközelítés már egy nagyon széles körű értelmezés, melybe gyakorlatilag végtelen számú tevékenység, aktivitás beleférhet, ami megerősíti a fogalom értelmezésének komplexitását. Ezért a tanulmányban ezt a CSR értelmezést használom.

\section{Vállalati önkéntesség}

Ahogy az előző alfejezetben szerepelt, a vállalatok nagyon sokféle olyan tevékenységet folytathatnak, amely megfeleltethető a CSR-nak. Az egyik ilyen tevékenység lehet a vállalati önkéntesség, amelyről a szakirodalomban az a konszenzus, hogy ez a tevekénység a CSR és a vállalatok társadalmi szerepvállalásának egyik eleme (például: Lee - Higgins 2001. cit. Mayer - Costa e Silva 2017; Lorenz et al. 2011; Molnár - Vida 2021).

A vállalati önkéntességnek sincs általános definíciója (Hetesi - Csovcsics 2015). Molnár Klára (2021:103) az alábbi módon közelíti meg a fogalmat: „A vállalati önkéntesség szerves része egy cég társadalmi felelősségvállalásának, melynek során a vállalat munkatársai munkaidőben vagy szabadidejükben valami fontos, értelemteli cselekvést hajtanak végre azzal a céllal, hogy hozzájáruljanak a társadalom, a közösség, és az egyes emberek jóllétéhez, kiemelten abban a közösségben, melyben a cég működik." Gammon és Ellison (2010), illetve Radácsi (2021) 
értelmezésében a vállalati önkéntesség olyan önkéntes tevekénység, ahol az aktivitás mögött ott áll a vállalat támogató, bátorító, ösztönző szerepben.

Peloza és Hassay (2006) alapján az alábbi kétféle vállalati önkéntességforma különböztethető meg:

- Szervezetközi (inter-organizational) önkéntesség, amikor a kezdeményező a munkavállaló, de a munkáltató támogatja, hogy például munkaidőben történjen az önkéntes tevékenység.

- Szervezeten belüli (intra-organiztaional) önkéntesség, amikor kezdeményező, szervező és támogató is egyben a munkáltató.

A vállalati önkéntesség még viszonylag új kutatási és gyakorlati területnek számít. Nemzetközi szinten az utóbbi években már számos kutatás, szakirodalom foglalkozott a témával, a hazai vállalati önkéntesség vizsgálata még csak néhány szerzőhöz, szervezethez ${ }^{4}$ köthető. Egyelőre nincs olyan kutatás, elemzés, mely feltárta volna a hazai jellemzők teljes spektrumát, így a téma gyakorlati vonatkozásai még hiányosak (Molnár 2021). Tanulmányommal a témakör elméleti részéhez kívánok további összefüggésekre, jelenségekre rávilágítani.

\section{Vállalati versenyképesség}

A vállalati versenyképesség fogalma is abba a kategóriába tartozik, amire nincs egy általánosítható, minden vállalatra egységesen használható megfogalmazás. A hazai és nemzetközi definíciók közül egyet szeretnék kiemelni, melyben a szerzők hozzákapcsolják a társadalmi felelősségvállalás jelenségét a vállalati versenyképességhez, így ezt témám szempontjából releváns megközelítésnek tartom: „A vállalati versenyképesség felfogásunkban a vállalatnak azon képessége, hogy a társadalmi felelősség normáinak betartása mellett tartósan tud olyan termékeket és szolgáltatásokat kínálni a fogyasztóknak, amelyeket azok a versenytársak termékeinél inkább hajlandók a vállalat számára nyereséget biztosító feltételek mellett megfizetni. E versenyképesség feltétele, hogy a vállalat legyen képes a környezeti és a vállalaton belüli változások érzékelésére és az ezekhez való alkalmazkodásra a

\footnotetext{
${ }^{4}$ Hazánkban az Effekteam folytat kutatásokat a vállalati önkétesség körében, pl. 2011-ben a TOP 200 vállalat körében, melynek keretében 38 vállalat válaszolt a szervezet kérdéseire (Magyar Adományozói Fórum 2011); 2015-ben készült elemzés a vállalatok támogatási programjaiba történő munkavállalók bevonásáról (Magyar Adományozói Fórum 2015); 2016-ban a vállalati támogatások gyakorlatát térképezte fel a szervezet, mely érintette a vállalati önkéntesség témáját is (Magyar Adományozói Fórum 2016); 2021-ben a szervezet tagjainál mérték fel a társadalmi befektetések trendjeit (Effekteam 2021).
} 
versenytársainál tartósan kedvezőbb piaci versenykritériumok teljesítésével." (Czakó - Chikán 2007:3).

\section{A VÁLLALATI TÁRSADALMI FELELŐSSÉGVÁLLALÁS (CSR) LEHETSÉGES HATÁSA A VÁLLALATI VERSENYKÉPESSÉGRE}

Írásom középpontjában a vállalati önkéntesség versenyképességre gyakorolt lehetséges hatásának értelmezése áll, azonban mielőtt erre rátérek, egy tágabb kontextusból vezetem fel a témát. Mivel a vállalati önkéntesség a vállalati társadalmi felelősségvállalás (CSR) része, így először röviden a CSR oldaláról vizsgálom a kérdést, vagyis arra a kérdésre keresem a választ szakirodalmi előzmények alapján, hogy a CSR-nak lehet-e hatása a vállalati versenyképességre?

A vállalatok elsődleges célja a profitmaximalizálás, egy sikeres vállalattól elvárható, hogy legyen hatékony, legyen megfelelő jövedelemtermelő képessége, legyen versenyképes. Ezek mellett jelent meg több évtizede az a gondolat, hogy a vállalatok ennél többre is hivatottak, hiszen nemcsak gazdasági célokat tudnak szolgálni, hanem részt tudnak venni a társadalom formálásában is, sőt hatással is vannak a társadalmi folyamatokra. Így született meg a vállalati társadalmi felelősségvállalás (CSR) koncepciója. Eleinte ezt a tevékenységet egy teljesen önkéntes és a társadalmi célokat előtérbe helyezőnek gondolták, azonban ma már egyértelműen kijelenthető, hogy „egyetlen vállalkozástól sem várható el, hogy bármely tevékenységét tökéletesen nonprofit módon, nyereségmaximalizálási és vagyongyarapodási céljait teljes mértékben sutba dobva végezze." (Csonka et al. 2013:182). Ezen gondolatmenet alapján feltételezhető, hogy a CSR aktivitás nemcsak társadalmi érdekeket szolgál, hanem felfedezhetőek benne egyéni, vállalati érdekek is. Ez viszont azt jelenti, hogy a CSR tevékenységek mögött álló motiváció nemcsak altruista szempontokat jelent, hanem megjelennek benne a vállalat müködésére is ható eredmények, vagyis feltételezhető a versenyképességre való hatás is.

Felmerül a kérdés, hogy ez valóban így lehet-e minden vállalatnál? A CSR aktivitás számos tényezőtől függ, a téma szempontjából a legfontosabbnak a vállalati méret kérdését tartom. A CSR koncepciót eredetileg a nagyvállalatokra értelmezték (erre utal a corporate szó is), azonban ma már általánosan elfogadott tény (lásd. European Commission 2011), hogy bármilyen méretû vállalat végezhet CSR tevékenységet. Azonban azt is látni kell, hogy a 
nagyvállalatok és a kis- és közepes vállalatok CSR tevékenysége jelentősen eltérhet egymástól (például Jenkins 2004; Málovics 2009; EC 2011; Rasche et al. 2017; Szennay 2018; Ortiz-Avram 2018). Tudjuk ezt annak ellenére, hogy a szakirodalmi elemzések és az empirikus kutatások többsége még ma is a nagyvállalatokat vizsgálja, noha az utóbbi években már egyre több kisés közepes vállalati kutatás is megjelent (például Tantalo et al. 2012; Tomšič et al. 2015; Witjes et al. 2017; Zastempowski - Cyfert 2021).

A nagyvállalatokra sokkal inkább a formalizált CSR tevékenység jellemző és az aktivitás motivációja is eltérő lehet esetükben. A CSR-nak ezt a szintjét többféle elnevezéssel illeti a szakirodalom például: érdekvezérelt CSR (Török 2002); stratégiai CSR (Porter - Kramer 2006); üzleti indíttatású CSR (Rasche et al. 2017). Ezek mindegyike arra utal, hogy a CSR tevékenység hajtóereje alapvetően kapcsolódik a vállalat üzleti folyamataihoz és a tevékenységektől a vállalat a versenyképesség növekedését várja.

Porter és Kramer (2006) hangsúlyozzák, hogy a CSR tevékenységek versenyelőnyként való kezelése akkor lehet szempont, ha a CSR aktivitás egy tudatosan felépített stratégia mentén történik. Alapvetően a nagyvállalatok azok, amelyek képesek lehetnek ilyen formalizált tevékenységekre, a kis- és közepes vállalatok CSR tevékenysége kevésbé tudatos. Ez természetesen nem jelenti azt, hogy egy kis- és közepes vállalat nem várhat versenyelőnyt a CSR aktivitásától, azonban ezt jellemzően nem direkt elvárásként fogalmazzák meg. A másik szempont, hogy a versenyelőnyt akkor lehet kimutatni, ha a vállalat képes mérni a CSR tevékenységek eredményét és tudja azt számszerúsíteni. Erre akkor lehet képes egy vállalat, ha tudatosan építi fel a CSR aktivitását, áll mögötte egy stratégia, egy szervezeti rendszer, ami képes megjeleníteni a CSR-nak ezt a magasabb szintjét is, ami azért tegyük hozzá, nem is olyan egyszerű, mert még ha tudatos és formalizált is a CSR aktivitás, akkor is nagyrészt szubjektív tényezők összessége, amit nehéz számokkal kifejezni (Csonka et al. 2013). A kis- és közepes vállalatok esetében a CSR aktivitás mögött ritkábban lehet ilyen tudatos elszámolás, ha van is versenyelőnye a CSR-nak, ezek inkább emberi tényezők vagy olyanok, amelyek közvetetten hatnak a múködésre és kevésbé mutathatók ki pénzügyi mutatókkal.

Összességében megállapítható, a CSR versenyképességhez való hozzájárulása ${ }^{5}$ értelmezhető, azonban ez közvetlenül inkább a nagyvállalatok esetében lehet releváns, mert ott található nagyobb valószínúséggel olyan szinten stratégiailag is megalapozott CSR tevékenység,

\footnotetext{
${ }^{5}$ Az első hazai kutatások egyike a Csillag Sára (2008) által bemutatott interjús kutatás a témában.
} 
amelynek alapján a hatások számszerüsíthetők és a versenyelőnyök kimutathatók ${ }^{6}$. A kis- és közepes vállalatok esetében egy sokkal informálisabb aktivitás jellemző, melyek motivációja mögött kevésbé üzleti célok állhatnak, de természetesen a pozitív hatások, a gazdasági értékteremtés itt is megjelenhetnek.

\section{A VÁlLALATI ÖNKÉNTESSÉG LEHETSÉGES HATÁSA A VÁLLALATI VERSENYKÉPESSÉGRE}

\section{A vállalati méret szerepe}

Az előző alfejezetben láthattuk, hogy a CSR nemcsak önérdek nélküli tevékenység lehet, hanem lehetséges - pénzügyileg kimutatható vagy nem kimutatható formában - hatása a vállalati versenyképességre is. Mivel a vállalati önkéntesség a CSR része, így felmerülhet a kérdés, hogy önállóan egy adott CSR tevékenységnek is tudjuk-e értelmezni az ilyen irányú hatását?

A CSR esetében megállapítottam, hogy a vállalati méretből érdemes kiindulni, mert a nagyvállalatok és a kis- és közepes vállalatok CSR tevékenysége jelentősen eltérhet egymástól - ez igaz a vállalati önkéntességre is (Lorenz et al. 2011; Lough - Turner 2017; Mayer - Costa e Silva 2017; Molnár 2021). A vállalati önkétesség szervezeten belüli formában, akár stratégiával alátámasztva jellemzően a nagyvállalatok körében fordul elő, ez természetesen nem jelenti azt, hogy kis- és közepes vállalatok esetében nem találkozunk ilyen típusú aktivitással. Esetükben azonban kevésbé szervezett ez a tevékenység és inkább a szervezetközi önkéntességgel írható le a gyakorlat.

A CSR versenyképességre való hatását közvetlenül, számszerű formában kimutathatóan szintén jellemzően a nagyvállalatok körében találjuk meg, így feltételezhető, hogy a vállalati önkéntesség ilyen típusú hatása is inkább ezen vállalatok körében értelmezhető inkább. Azonban mind a vállalati önkéntesség témája és ezáltal mind a versenyképességre való hatása keveset kutatott téma, és még nemzetközi környezetben sem történt annyi vizsgálat, amelyből általánosítható következtetéseket lehessen levonni. Magyarországon az elmúlt években történtek felmérések a témában, de így is megállapítható, hogy „mindezen kutatások

\footnotetext{
${ }^{6}$ Az elmúlt néhány évtizedben nemzetközi szinten nagyon sok olyan elemzés született, amely a CSR és a vállalati teljesítmény közötti kapcsolatot vizsgálta empirikusan, többségük pozitív irányú összefüggést mutatott ki, de vannak olyan kutatási eredmények is, amelyek negatív vagy semleges kapcsolatot tártak fel.
} 
megléte ellenére [...] a hazai vállalati önkéntesség vizsgálata a mai napig feltáratlan terület, nem állnak rendelkezésre rendszeres és a teljes vállalati szektort lefedő kutatások, elemzések. Így a rendelkezésre álló információk részlegesek." (Molnár 2021:104).

A fentiekben azt hangsúlyoztam, hogy a vállalati önkéntesség alapvetően nagyvállalati gyakorlat, azonban a hazai felmérések egyértelműen azt mutatják, hogy még körükben sem általános ez a tevékenység. A Magyar Adományozói Fórum (mai nevén Effekteam) 2011-ben végzett kutatást a magyarországi TOP200 vállalat körében, melynek keretében mindössze 38 vállalat válaszolt a kérdésekre, a többi vállalat egy részénél egyértelmű, nagyobb részénél feltételezhető volt, hogy azért nem vállalták a kutatásban való részvételt, mert nincs náluk vállalati önkéntesség. A szervezet az ilyen témájú kutatásokban aktív volt az elmúlt években is (lásd második lábjegyzet), a kutatásaik megerősítették, hogy a hazai nagyvállalatok nem aktívak a vállalati önkéntességben: „Így tehát, az Effekteam - 2011-2013 között, illetve 2015 és 2016-ban készült - elemzései alapján azt mondhatjuk, hogy az elmúlt 10 évben körülbelül minden negyedik, illetve ötödik nagyvállalatnál volt fellelhető valamilyen formában a vállalati önkéntesség." (Molnár 2021:104). Úgy gondolom, hogy az ilyen típusú kutatások és a szakirodalmi elemzések segíthetik a vállalatokat a vállalati önkéntesség és CSR tevékenységek kibontakozásában, fejlesztésében, mert rávilágíthatnak olyan összefüggésekre, melyek hatással lehetnek a vállalatok gondolkodására, társadalmi nyitottságára.

\section{Elönyök és hatások mérése}

Ahhoz, hogy egy vállalat bevezesse ezt a fajta aktivitást, természetesen megfelelő motiváció szükséges és azt is látnia kell, hogy milyen előnyök származhatnak a tevékenységböl. A korábbi, nemzetközi szakirodalmi elemzések szerint a vállalatok alapvető motivációja lehet, hogy ezáltal alkossanak valami új dolgot a társadalom számára és javítsák a munkavállalók kompetenciáit (Wilson 2000; Basil et al. 2009. cit. Brzustewicz et al. 2022). Az Effekteam 2011es kutatása (TOP200 vállalati körében, 38 válaszadó) az alábbi motivációs tényezőket tárta fel: a csapategység fejlődése, a vállalat hírnevének, a munkavállalók elégedettségének és lojalitásának növekedése (Molnár 2021). Egy négy évvel későbbi felmérésben (Molnár 2021) a vállalat iránti elkötelezettség növekedését, a munkahelyi hangulat javítását és az együttmúködési készségek fejlesztését fogalmazták meg a legtöbb esetben. Véleményem szerint az is egy fontos tényező lehet a vállalati önkéntesség kialakításában, hogy milyen igényre reagál a vállalat ezzel a tevékenységgel, vállalati vagy társadalmi igényt próbál 
kielégíteni? Egyáltalán meg tudja-e fogalmazni magának, hogy mi a fő motiváció? Az is további szempont lehet, hogy egyáltalán kinek fontos az önkéntesség ilyen irányú támogatása a vállalatnál, szervezeti szintű elköteleződés vagy egyéni szintű jellemző-e. Ez utóbbi alatt azt értem, hogy a vállalati önkéntesség filozófiája és gyakorlata még kevéssé, vagy nem épült be a vállalati szervezeti rendszerbe, inkább csak a vezetők/tulajdonosok preferenciája határozza meg ezeket.

Az önkéntességi programok meghirdetését az is segítheti, ha a vállalat tudja, hogy milyen előnyök származhatnak a tevekénységből. A kérdéssel foglalkozó szakirodalom kutatási eredményekre alapozva a vállalati önkéntesség számos előnyét mutatta már ki. Az 1. táblázatban a lehetséges előnyöket sorolom fel, kiegészítve néhány további szemponttal ${ }^{7} \mathrm{az}$ alábbiak szerint:

- Az előnyöket két nagy csoportra bontottam: a vállalat külső megítéléshez (külső előnyök) és a munkavállalókhoz kapcsolódókra (belső előnyök).

- A második osztályozási szempont az volt, hogy a kis- és közepes vállalatok és/vagy a nagyvállalati körben értelmezhető-e az adott előny: alapvetően szervezett formában a nagyvállalatokra jellemző a vállalati önkéntesség, de jelen van kisebb vállalatoknál is, így az előnyök is értelmezhetők mind a nagyvállalatokra, mind a kis- és közepes vállalatokra is. $\mathrm{A}$ táblázatban jelöltem, hogy melyek azok a tényezők, amelyek megítélésem szerint az adott vállalati méret esetében relevánsak lehetnek.

- További osztályozási szempont volt, hogy az adott előnyt közvetlenül (D - direct változó) vagy közvetetten (I - indirect változó) lehet-e kapcsolni a versenyképesség-növeléshez: úgy gondolom, hogy mindegyik előny vezethet a vállalat versenyképességének növekedéséhez, de ezek egy része csak közvetetten értelmezhető.

- Végül a negyedik osztályozási szempont arra vonatkozott, hogy a versenyképesség növelő hatás mely esetekben mutatható ki mérhető formában is: általában a társadalmi felelősségvállalásról megállapítható, így a vállalati önkéntességre is igaz, hogy nehezen mérhető vagy számszerűsíthető, mert a tevekénység jellegéből adódóan gyakran szubjektív megközelítés jellemzi (Csonka et al. 2013). Ettől függetlenül azonban lehetnek olyan

\footnotetext{
${ }^{7}$ A táblázat kitöltése a saját, korábbi szakirodalmi és kutatási tapasztalataim alapján készült.
} 
előnyök, amelyek akár pénzügyileg is kimutathatók, így versenyképességhez való hozzájárulásuk láthatóvá válik.

1. táblázat $A$ vállalati önkéntesség lehetséges elönyei és szempontjai

\begin{tabular}{|c|c|c|c|c|}
\hline Előnyök & $\begin{array}{l}\text { Kis- és közepes } \\
\text { vállalat }\end{array}$ & Nagyvállalat & $\begin{array}{l}\text { Versenyképesség } \\
\text { növelés: } \\
\text { közvetlenül (D); } \\
\text { közvetetten (I) }\end{array}$ & $\begin{array}{l}\text { Versenyképesség } \\
\text { növelö lehet - } \\
\text { mérhető formában } \\
\text { is }\end{array}$ \\
\hline \multicolumn{5}{|c|}{ KÜLSŐ } \\
\hline $\begin{array}{l}\text { Jobb megítélés a } \\
\text { környezet által }\end{array}$ & $\mathrm{x}$ & $x$ & 1 & \\
\hline Új kapcsolatok & $x$ & $x$ & D & \\
\hline $\begin{array}{c}\text { Érintettek általi jobb } \\
\text { megítélés }\end{array}$ & & $\mathrm{x}$ & 1 & \\
\hline $\begin{array}{l}\text { Társadalmi környezet } \\
\text { segítése }\end{array}$ & $x$ & $x$ & 1 & \\
\hline A márkaépítés segítése & & $x$ & D & $x$ \\
\hline Vevői elégedettség & $\mathrm{x}$ & $x$ & D & $x$ \\
\hline $\begin{array}{l}\text { A bizalom növekedése a } \\
\text { társadalomban és a } \\
\text { gazdaságban }\end{array}$ & & $x$ & 1 & \\
\hline \multicolumn{5}{|c|}{ BELSŐ } \\
\hline $\begin{array}{c}\text { Boldogabb } \\
\text { munkavállaló (ezáltal } \\
\text { jobb teljesítmény lehet) }\end{array}$ & $\mathrm{x}$ & $\mathrm{x}$ & D & $\mathrm{x}$ \\
\hline $\begin{array}{l}\text { Jobb munkahelyi } \\
\text { hangulat (ezáltal jobb } \\
\text { teljesítmény lehet) }\end{array}$ & $x$ & $x$ & D & $x$ \\
\hline $\begin{array}{c}\text { Fejlődnek a } \\
\text { munkavállalói } \\
\text { készségek (ezáltal jobb } \\
\text { teljesítmény lehet) }\end{array}$ & $\mathrm{x}$ & $\mathrm{x}$ & D & $\mathrm{x}$ \\
\hline $\begin{array}{c}\text { A bizalom növekedése a } \\
\text { munkahelyen }\end{array}$ & $x$ & $x$ & D & \\
\hline $\begin{array}{l}\text { Elkötelezettebb } \\
\text { munkavállaló }\end{array}$ & $\mathrm{x}$ & $\mathrm{x}$ & D & \\
\hline
\end{tabular}

Forrás: Gammon - Ellison 2010; Basil et al 2011; Molnár 2012; 2021; Brzustewicz et al 2022 alapján saját szerkesztés

Megjegyzés: A táblázatban az előnyök felsorolása készült a hivatkozott irodalmak alapján, a táblázat többi részének kitöltése saját szempontok, tapasztalatok alapján történt.

A versenyképességre gyakorolt hatás minden tevekénység esetében akkor mutatható ki, ha egyfelől ezek a tényezők azonosításra kerülnek, másfelől, ha az adott aktivitásoknak tudjuk, hogy konkrétan milyen hatásuk, eredményük lehet. Így van ez a vállalati önkéntességgel is. $A$ vállalati önkéntesség értékelésének alapja lehet magának az önkéntes tevekénységnek az általános értékelése. Egyrészt itt is megjelenhet a gazdaságra, társadalomra, másrészt a 
szervezeti szintre is kifejtett hatása. Ez utóbbi kétoldalú hatás, ugyanis kimutatható magára a vállalatra, annak munkavállalóira, illetve arra a szervezetre, ügyre is gyakorolt hatás, amire a tevékenység irányul.

Az Effekteam hazai kutatásai kimutatták (Molnár 2021), hogy hazánkban még nagyvállalati körben sem gyakori és általános a vállalati önkéntesség hatásainak mérése. Ez azért probléma, mert „utánkövetés, mérés nélkül nagyon nehéz megmondani, vajon jó úton jár-e a cég, a kitúzött célok megvalósultak-e, illetve meg valósulnak-e." (Molnár 2021:118). Ehhez kiegészítésként hozzá kell tenni, hogy ha már ezt sem tudja a vállalat, akkor azt sem fogja tudni megállapítani, hogy hozzájárult-e egyáltalán valamilyen nagyobb társadalmi, gazdasági célhoz, és milyen értéket teremtett a tevekénység menedzselésével. Az értékelés fontos lenne, Molnár Klára (2021) és Radácsi László (2021) gondolatait továbbgondolva az alábbi lehetséges szempontok miatt ${ }^{8}$ :

- Minden tevékenységnek van célja, fontos tudni, hogy ezek megvalósultak-e? Mi lett az aktivitás eredménye?

- Milyen erőforrásokat kellett felhasználni?

- Elégedettek-e az érintettek?

- Kinek, milyen előnye származott a tevékenységből?

- Kiknek teremtett értéket a tevékenység?

- Kire, hogyan hatott a tevékenység?

- Kell-e fejleszteni a tevékenységen a jövőben?

A kérdésekre adott válaszok egy része megadhatók mennyiségi mutatókkal, vagyis számszerüsíthető az eredmény és a hatás. Azonban sok esetben csak szubjektív módon mutathatók ki, így a versenyképességre való hatás is közvetett lehet (1. táblázat). A hazai felmérések azt mutatják (Molnár 2021; 2012), hogyha van is bármilyen adatgyűjtés, információgyújtés a vállalatoknál, az leginkább arra terjed ki, hogy hány munkavállaló, hány órában végzett önkéntes munkát. Arra vonatkozóan, hogy mindez hogyan hatott a munkavállalókra, a vállalatra gazdasági és társadalmi szempontból, csak feltételezésekkel tudnak élni, mert konkrét adatgyűjtés nem jellemző. Összevetve ezt általában az önkéntesség (tehát nem egy részterületre vonatkozó) értékelésével megállapítható, hogy az önkéntesség

\footnotetext{
${ }^{8}$ Hozzáteszem, hogy nemcsak a vállalati önkéntesség esetében, hanem más tevékenységeknél is szempont lehet ezen kérdések mentén az értékelés.
} 
hatásának értékelése kapcsán jellemzően inkább a tevekénység társadalmi jelentőségének vizsgálata kidolgozott, nemzetgazdasági szempontú értékelés (az önkéntesség nem ingyen munka) kevésbé (Bartal et al. 2021).

A vállalati önkéntesség esetében - ahogy arra fentebb már kitértem röviden - még összetetteb az értékelés, mert itt megjelenik a vállalatokra gyakorolt hatás is, viszont magának a tevékenység értékének megjelenítése nemzeti szinten is fontos. A vállalati önkéntesség értékelése tehát egyrészt megjelenhet általánosságban az önkéntesség értékelésében, másrészt a vállalathoz kapcsolódóan is.

Amennyiben mélyebben elmerülünk a témában azzal kapcsolatban, hogy milyen hatásokat tud kiváltani a vállalati önkétesség, akkor kiderül, hogy sokkal összetettebb a jelenség, mint azt elsőre gondolnánk. Hatása lehet a munkavállalók életére, a vállalat múködésére, megítélésére, a vállalat szűkebb, tágabb környezetére, a társadalmi és a gazdasági folyamatokra. Kutatóként az a véleményem, hogy az ilyen alapos és minden részletre kitérő elemzésre csak olyan vállalatok lehetnek képesek, ahol eleve jelentős számú munkavállaló végez önkéntes aktivitást, ami széles körűen tud hatást kiváltani. Másrészt olyan menedzsment háttere van a tevékenységnek, amely képes arra, hogy adatokat, információt gyűjtsön, elemezzen és komplexen átlássa a teljes folyamatot és értékelni is tudja. Ilyen szintű gyakorlati elemzésre eddig alig van példa.

Kutatói oldalról egy 2017-ben megjelent tanulmányban (Mayer - Costa e Silva 2017) olvashatunk egy részletes értékelemző modellt, mely kísérletet tesz arra, hogy a vállalati önkétesség hatását a lehető legszélesebb értelemben számszerúsíthető módon kimutassa ${ }^{9}$. A szerzők Haldane (2014) hagymamodelljét fejlesztették tovább. Az eredeti modellben társadalmi, személyes/egyéni és gazdasági értékeket azonosítottak általánosságban az önkéntesség előnyeként. Ezt kibővítve Mayer és Costa e Silva (2017), az egyéni érték kategóriát két részre bontották: vállalati és nem vállalati tényezőkre és kimondottan a vállalati önkéntességre készítették el a modelljüket.

- A vállalati szintű értékteremtés alatt a következőket értették: növekvő produktivitás, nagyobb elköteleződés, vonzóbb munkahely, képességek fejlődése, hírnév növekedése.

\footnotetext{
9 A tanulmányban említés szintjén megjelennek további vállalati önkétességet értékelő modellek (pl. Volunteerism ROI Tracker model, London Benchmarking Group model, Boston College Center for Corporate Citizenship model), de ezeket kevésbé tekintik átfogónak a saját modelljükhöz képest.
} 
- A nem vállalati kategóriába sorolták az alábbiak: növekvő jóllét, egészségügyi előnyök, növekvő foglalkoztatottság. A társadalmi értékek a társadalmi problémákra való reagáláshoz köthetők, a gazdaságiak pedig az önkéntesség pénzügyileg is megragadható oldalához kapcsolódnak.

A szerzők arra is vállalkoztak, hogy az egyes értéktényezőkhöz, ahol értelmezhető, pénzösszegeket rendeltek egy konkrét vállalat esetében (a vizsgált vállalat Portugáliában múködik, 12 ezer munkavállalója van, akik közül 2015-ben körülbelül 2400 fő volt önkéntes). Az eredmények szerint a vállalati önkéntesség gazdasági értéke tette ki a legkisebb arányt a teljes értékmennyiségből, a legnagyobb aránnyal a társadalmi szerepel, 70,5 százalékkal.

Ha a felállított modellt jéghegyként ábrázoljuk, akkor a gazdasági rész az, ami a felszín felett van, vagyis látható szinten, a többi része láthatatlan. Ezzel arra utaltak a szerzők, hogy bár arányaiban ez a nagyobb rész, mégis ezt nehezebb meglátni és mérni is. A továbbfejlesztett modell előnye, hogy több értéktényezőt, kimondottan a vállalati önkéntességre vonatkoztatva vizsgál, felhívva a figyelmet arra, hogy a vállalati önkéntesség nemcsak gazdasági értéket teremt, hanem ennél sokkal összetettebb a hatása. Ez a módszer egy kiváló eszköz lehet a vállalatok számára, és segítheti őket abban, hogy jobban megértsék a vállalati önkéntesség folyamatát és az általa generált hatásokat és az általa teremtett értékeket. Úgy gondolom, hogy a modell alkalmas lehetne nemcsak egy tevékenység, hanem akár a teljes CSR aktivitás értékelésére is, természetesen akkor, ha rendelkezésre állnak megfelelő adatok.

\section{ÖSSZEGZÉS}

A tanulmány célja az volt, hogy áttekintést adjon a vállalati önkéntesség vállalati versenyképességre gyakorolt lehetséges hatásairól. A vállalati társadalmi felelősségvállalásról ma már kijelenthető, hogy nemcsak egy önként vállalt feladata a vállalatoknak, hanem olyan tevekénységeket is jelenthet, amelyek mögött vállalati önérdek is állhat, amiben a pénzügyi előnyök is szerepet játszhatnak. Ez a szemlélet sok tényezőtől függhet. A tanulmányban elsődlegesen a vállalati méretet emeltem ki, hiszen - bár ma már bármilyen méretű vállalat aktív lehet a CSR terén - formalizált, stratégiai szintű CSR, amitől versenyelőnyt is lehet remélni alapvetően a nagyvállalatok körében fordul elő még ma is, mind nemzetközi, mind hazai környezetben. 
Ezen alapokra építve a fő kérdésem az volt, hogy ha a CSR esetében lehet a vállalati versenyképességet vizsgálni, akkor lehet-e ezt egy meghatározott tevékenységére is, a vállalati önkéntességre vonatkozóan is? A kérdés megválaszolása érdekében szakirodalmi elemzést készítettem, ez alapján megvizsgáltam, hogy az elmúlt években megjelent tanulmányokban milyen módon vetődik fel a hazai és a nemzetközi tudományos életben a téma. Megállapítottam, ahogy a CSR esetében is, úgy a vállalati önkéntesség vállalati versenyképességre gyakorolt lehetséges hatásainál is, széles a nemzetközi szakirodalom. Ugyanakkor a hazai tanulmányok száma alacsony, nemcsak a vállalati önkéntesség és versenykésesség kapcsolatát illetően, hanem egyáltalán a vállalati önkéntesség témájában is. Az utóbbi 10 évben az Effekteam szervezet volt aktív hazai kutatások lefolytatásában, de a hazai vállalati önkéntesség vizsgálata még így nagyon sok további potenciált rejt magában.

Egyértelműen a mellett foglaltam állást, hogy a vállalati önkéntességnek lehet hatása a vállalati versenyképességre, azonban ehhez a vállalatnak értékelni kell tudnia a tevékenységet (számszerúleg is), fel kell tudnia mérni, hogy milyen hatásokat generálhat az ilyen típusú aktivitás. Úgy gondolom, hogy ma még kevés az olyan vállalat, amely e téren képes tudatosan múködni, hiszen egy komplex hatásmérés nagyon sok erőforrást kíván meg. Viszont lehet olyan eset is, amikor egy vállalat nem is akar például számszerűsíthető hatásokat kimutatni, ennek ellenére múködése során mégis érzékeli a vállalati önkéntesség előnyeit, melyet beépít a vállalati múködésbe.

Annyira összetett világban élünk ma már, hogy nehéz olyan elemzést készíteni, mely minden szempontot figyelembe tud venni, természetesen törekedni lehet rá, de azt be kell látni, hogy minden vállalat más és más, így szinte lehetetlen általános igazságokat megfogalmazni velük kapcsolatban. Azonban fel lehet villantani szempontokat, rá lehet mutatni jelenségekre, melyek útmutatóul szolgálhatnak a vállalatok számára és el tudják dönteni, hogy az adott múködési környezetben, mely tényezők lesznek azok, amelyekkel azonosulni tudnak. Bízom benne, hogy tanulmányomban fellelhetők ilyen gondolatmorzsák, amelyek továbbgondolása révén újabb és újabb kutatások születhetnek és fejlődhet a vállalati gyakorlat. 


\section{IRODALOM}

András István - Rajcsányi-Molnár Mónika (2014): Profit és filantrópia. A CSR eszmetörténeti kérdései. Civil Szemle, 11(2) pp. 5-23.

Bartal Anna Mária - Perpék Éva - Nagy Réka (2021): Ingyen munkaerő-e az önkéntes? Önkéntes Szemle, 1(4) pp. 57-75. DOI: 10.53585/OnkSzem.2021.4.57-75

Basil, Debra - Runte, Mary - Basil, Michael - Usher, John (2011): Company support for employee volunteerism: Does size matter? Journal of Business Research, 64 pp. 61-66. DOI: 10.1016/j.jbusres.2009.10.002

Basil, Debra Z. - Runte, Mary S. - Easwaramoorthy, M. - Barr, Cathy (2009): Company Support for Employee Volunteering: A National Survey of Companies in Canada. Journal of Business Ethics, 85(2) pp. 387398. DOI:10.1007/s10551-008-9741-0

Bowen, Howard R. (1953): Social responsibilities of the businessman. No. 3. New York: Harper \& Brothers.

Brzustewicz, Paweł - Escher, Iwona - Hatami, Akram - Hermes, Jan - Keränen, Anne - Ulkuniemi, Pauliina (2022): Emergence of social impact in company-NGO relationships in corporate volunteering. Journal of Business Research, 140(C) pp. 62-75. DOI: 10.1016/j.jbusres.2021.11.089

Carroll, Archie B. - Shabana, Kareem M. (2010): The Business Case for Corporate Social Responsibility: A Review of Concepts, Research and Practice. International Journal of Management Reviews, 12(1) pp. 85-105. DOI: 10.1111/j.1468-2370.2009.00275.x

Carroll, Archie B. (1979): A three-dimensional conceptual model of corporate social performance. Academy of Management Review, 4 pp. 497-505.

Carroll, Archie B. (1991): The pyramid of corporate social responsibility: toward the moral management of organizational stakeholders. Business Horizons, 34(4) pp. 39-48. DOI: 10.1016/00076813(91)90005-G

Czakó Erzsébet - Chikán Attila (2007): Gazdasági versenyképességünk vállalati nézőpontból - 20042006. Vezetéstudomány, 38(5) pp. 2-8. DOI: 10.14267/VEZTUD.2007.05.01

Csillag Sára (2008): Vállalatok társadalmi felelössége és a versenyképesség - Versenyben a világgal 2007-2009 címü kutatás. 50. sz. mühelytanulmány. Budapest: Budapesti Corvinus Egyetem, Vállalatgazdaságtan Intézet, Versenyképesség Kutató Központ.

Csonka Arnold - Szabó-Szentgróti Eszter - Kőmúves Zsolt - Szabó-Szentgróti Gábor - Borbély Csaba (2013): Nyereséges vállalati múködés vs társadalmi felelősségvállalás. Acta Scientiarum Socialium, 39 pp. 181-188.

Davis, Keith (1960): Can business afford to ignore social responsibilities? California Management Review, 2(3) pp. 70-76.

European Commission (EC) (2011): A renewed EU strategy 2011-14 for Corporate Social Responsibility. Brussels.

Gammon, Anne - Ellison, Gavin (2010): Volunteering is the Business Employers' and employees' attitudes to workplace based volunteering. London: National Young Volunteers Service.

Haldane, Andrew G. (2014): In giving, how much do we receive? The social value of volunteering. A Pro Bono Economics lecture to the Society of Business Economists, London. https://www.bankofengland.co.uk/-/media/boe/files/speech/2014/in-giving-how-much-do-wereceive-the-social-value-of-volunteering Letöltve: 2022. 01. 10.

Hetesi Erzsébet - Csovcsics Andrea (2015): Volunteering as a part of CSR and company support for employee volunteering. Responsibility and Sustainability, 3(3) pp. 3-14. 
Jenkins, Heledd M. (2004): A Critique of Conventional CSR Theory: An SME Perspective. Journal of General Management, 29(4) pp. 37-57. DOI: 10.1177/030630700402900403

Kotler, Philip - Lee, Nancy (2007): Vállalatok társadalmi felelősségvállalása. Budapest: HVG Kiadó Zrt. Lee, Louise - Higgins, C. (2001): Corporate volunteering: Ad hoc interaction or route to dialogue and partnership? Journal of Corporate Citizenship, 4 pp. 79-90. DOI: 10.9774/GLEAF.4700.2001.wi.00008 Lorenz, Christian - Gentile, Gian-Claudio - Wehner, Theo (2011): How, why, and to what end? Corporate volunteering as corporate social performance. Int. J. Business Environment, 4(2) pp. 183205. DOI: 10.1504/IJBE.2011.040174

Lough, Benjamin J. - Turner, Yvonne Siu (2017): How to Accelerate Volunteering through Employee Volunteer Programmes. Journal of Corporate Citizenship, 67 pp. 77-94. DOI: 10.9774/TandF.4700.2017.se.00006

Málovics György (2009): A vállalati fenntarthatóság érintettközpontú vizsgálata. Doktori értekezés. Pécs: Pécsi Tudományegyetem.

Mayer, Jorge M. L. P. - Costa e Silva, Susana (2017): Exploring the Whole Value of Corporate Volunteering. Journal of Corporate Citizenship, 67 pp. 95-119. DOI: 10.9774/T\&F.4700.2017.se.00007 Molnár Klára (2012): Vállalati önkétesség Magyarországon, 2011. Civil Szemle, 4 pp. 31-48.

Molnár Klára (2021): A nagyvállalati önkéntesség az elmúlt 10 évben - az Effekteam vizsgálatainak tükrében. Önkéntes Szemle, 1(4) pp. 102-122. DOI: 10.53585/OnkSzem.2021.4.102-122

Molnár Klára - Vida Vivien (2021): Vállalati önkéntesség a gyakorlatban. Önkéntes Szemle, 1(4) pp. 7693. DOI: 10.53585/OnkSzem.2021.4.76-93

Ortiz-Avram, Daniela - Domnanovich, Julia - Kronenberg, Christopher - Scholz, Markus (2018): Exploring the integration of corporate social responsibility into the strategies of small- and mediumsized enterprises: A systematic literature review. Journal of Cleaner Production, 201 pp. 254-271. DOI: 10.1016/j.jclepro.2018.08.011

Peloza, John - Hassay, Derek N. (2006): Intra-organizational Volunteerism: Good Soldiers, Good Deeds and Good Politics. Journal of Business Ethics, 64 pp. 357-379. DOI: 10.1007/s10551-005-5496-z

Porter, Michael E. - Kramer, Mark R. (2006): 'The competitive advantage of corporate philanthropy'. Harvard Business Review, 80(12) pp. 56-69.

Radácsi László (2021): Felelős és fenntartható vállalat. Budapest: Saldo.

Rasche, Andreas - Morsing, Mette - Moon, Jeremy (2017): The Changing Role of Business in Global Society: CSR and Beyond. In: Rasche, A. - Morsing, M. - Moon, J. (szerk.): Corporate Social Responsibility -Strategy, Communication, Governance. Cambridge: Cambridge Univesrity Press, pp. 128.

Sarkar, Soumodip - Searcy, Cory (2016) Zeitgeist or chameleon? A quantitative analysis of CSR definitions. Journal of Cleaner Production, 135. pp. 1423-1435. DOI: 10.1016/j.jclepro.2016.06.157

Szennay Áron (2018): Nagyvállalatok pénzügyi teljesítményének és társadalmi felelősségvállalásának összefüggései Magyarországon. Közgazdasági Szemle, LXV(december) pp. 1280-1298. DOI: 10.18414/KSZ.2018.12.1281

Tantalo, Caterina - Caroli, Matteo G. - Vanevenhoven, Jeff (2012): Corporate social responsibility and SME's competitiveness. Int. J. Technology Management, 58(1/2) pp. 129-151. DOI: 10.1504/IJTM.2012.045792

Tomšič, Nastja - Bojnec, Štefan - Simčič, Blaž (2015): Corporate sustainability and economic performance in small and medium sized enterprises. Journal of Cleaner Production, 108 pp. 603-612. DOI: 10.1016/j.jclepro.2015.08.106 
Török Ádám (2002): Az etikus vállalati magatartás. és annak „filantróp csapdája”. Közgazdasági Szemle, XLIX(május) pp. 441-454.

Wilson, John (2000): Volunteering. Annual Review of Sociology, 26, pp. 215-240.

Witjes, Sjors - Vermeulen, Walter J. V. - Cramer, Jacqueline M. (2017): Exploring corporate sustainability integration into business activities. Experiences from 18 small and medium sized enterprises in the Netherlands. Journal of Cleaner Production, 153 pp. 528-538. DOI: 10.1016/j.jclepro.2016.02.027

Zastempowski, Maciej - Cyfert, Szymon (2021): Social responsibility of SMEs from the perspective of their innovativeness: Evidence from Poland. Journal of Cleaner Production, 317(128400) DOI: 10.1016/j.jclepro.2021.128400

Internetes dokumentumok:

Effekteam (2021): Társadalmi befektetések az Effekteam tagjainál - trendek 2021. https://effekteam.hu/wp-content/uploads/2021/03/T\%C3\%A1rsadalmi-befektet\%C3\%A9sek-azEffekteam-tagjain\%C3\%A1l-trendek-2021-1.pdf Letöltve: 2021. 12. 20.

Magyar Adományozói Fórum (2011): Vállalati önkéntesség (TOP200). https://effekteam.hu/wpcontent/uploads/2019/06/vallalati_onkentesseg_2011.pdf Letöltve: 2021. 12. 20.

Magyar Adományozói Fórum (2015): A munkavállalók bevonásának szerepe a vállalatok támogatási programjaiban 2015 (TOP 200+pénzügyi szektor). Kutatási Jelentés. https://effekteam.hu/wpcontent/uploads/2019/06/a_munkavallalok_bevonasanak_szerepe_a_vallalatok_tamogatasi_progra mjaiban_2015tanulmany.pdf Letöltve: 2021. 12. 20.

Magyar Adományozói Fórum (2016): Vállalatok támogatási gyakorlata 2016 (TOP 200 és pénzügyi szektor).

https://effekteam.hu/wp-

content/uploads/2019/06/kutatasi_osszefoglalo_vallaltok_tamogatasi_tevekenysege_2016.pdf Letöltve: 2021. 12. 20. 